\title{
Powierzchniowe stopowanie mikroplazmowe jako nowe podejście w zakresie modyfikacji biomateriałów tytanowych
}

\author{
Surface microplasma alloying as a new approach \\ to modification of titanium biomaterials
}

\section{Streszczenie}

W pracy przedstawiono wyniki badań modyfikacji warstwy wierzchniej tytanu metodą stopowania mikroplazmowego z użyciem nanoprekursorów proszkowych otrzymanych metodą mechanicznej syntezy o kompozycji wejściowej Ti+2\% oraz $10 \%$ wagowego dodatku boru. Zastosowanie prekursora nanokrystalicznego w istotny sposób wpływa na właściwości wyjściowe otrzymywanych warstw [1]. Prekursor nanokrystaliczny uzyskany w wyniku zastosowania procesu mechanicznej syntezy charakteryzuje się wysokim stopniem rozdrobnienia struktury oraz częściową amorfizacją. Zastosowanie nanoprekursora proszkowego w procesie modyfikacji warstwy wierzchniej z użyciem metody stopowania mikroplazmowego pozwala na uzyskanie struktury kompozytowej warstwy składającej się z faz: osnowy Ti (a) oraz wydzieleń TiB o wysokiej dyspersji, potwierdzonych badaniami strukturalnymi XRD [2]. Uzyskana przy doborze właściwych parametrów warstwa powierzchniowa, pozbawiona wad w postaci braku przetopu czy pęcherzy z jednoczesnym maksymalnym możliwym zakresem twardości charakteryzuje oczekiwany układ. Znaczący wzrost twardości uzyskany w warstwie powierzchniowej w stosunku do podłoża oraz poprawa odporności korozyjnej badanej w roztworze $0,9 \% \mathrm{NaCl}$ w próbie potencjodynamicznej, wskazuje na korzystną mikrostrukturę układu dwufazowego z wysokim stopniem rozdrobnienia. Przeprowadzone badania in vitro cytokompatybilności z użyciem linii ludzkich komórek fibroblastów oraz osteoblastów na powierzchniach modyfikowanych w odniesieniu do próbki bazowej tytanu mikrokrystalicznego [3] potwierdza, iż wytworzone układy mogą znaleźć potencjalne zastosowanie w zakresie modyfikacji implantów stomatologicznych czy też innych aplikacjach medycznych. Z przeprowadzonych analiz wynika, iż stopowanie mikroplazmowe jest efektywną metodą wytwarzania warstw kompozytowych typu Ti+TiB o możliwym szerszym aspekcie aplikacyjnym.

Słowa kluczowe: powierzchniowe stopowanie mikroplazmowe; mechaniczna synteza; testy cytokompatybilności; TiB

\section{Abstract}

The paper presents the results of modifcation of titanium surface by microplasma alloying using nano-powder precursors obtained by mechanical synthesis with $\mathrm{Ti}+2 \%$ input composition and $10 \%$ by weight boron addition. The use of nanocrystalline precursor significantly affects the initial properties of the obtained layers [1]. The nanocrystalline precursor obtained by the mechanical synthesis process is characterized by a high degree of fragmentation of the structure and partial amorphization. The use of nanoprecursor powder for the modification of the surface layer using microplasma alloying method allows to obtain a composite structure consisting of phases: the matrix $\mathrm{Ti}$ (a) and high dispersion TiB precursors, confirmed by XRD structural studies [2]. The surface layer obtained by selecting the appropriate parameters, free of defects such as lack of joint penetration or blisters, with the maximum possible hardness range characterizes the expected system. Significant increase of hardness obtained in the surface layer relative to the substrate and improvement of the corrosion resistance tested in the solution of $0.9 \% \mathrm{NaCl}$ in the potentiodynamic test indicates a favorable microstructure of the diphasic system with a high degree of fragmentation. The in vitro cytocompatible tests using human fibroblast cell lines and osteoblasts on modified surfaces with respect to the microcrystalline titanium base sample [3] confirm that the manufactured systems may find potential applications for the modification of dental implants or other medical applications. It has been observed that microplasma alloying is an effective method of producing Ti+TiB composite layers with a broader application aspect.

Keywords: plasma surface alloying; mechanical alloying; cytocompatibility tests; TiB

Dr inż. Andrzej Miklaszewski - Politechnika Poznańska,

dr Mariusz Kaczmarek; dr hab. n. med. Mieczysława U. Jurczyk, prof. nzw. UM - Uniwersytet Medyczny w Poznaniu.

Autor korespondencyjny/Corresponding author: andrzej.miklaszewski@put.poznan.pl 


\section{Wstęp}

W ostatnim dziesięcioleciu istotną uwagę w odniesieniu do grupy biomateriałów przykłada się do prowadzonych badań interdyscyplinarnych łączących w sobie różne obszary wiedzy i zagadnień. Istotnym w odniesieniu do powyższych pozostają zarówno czynniki kontrolujące właściwości oraz strukturę wewnętrzną materiału, jego odpowiedni kształt, a także te związane z relacją oddziaływań powierzchniowych z żywą tkanką [4]. Manipulacje z poziomu powierzchni materiału wydają się być względnie najłatwiejszym kierunkiem możliwego wdrożenia nowych podejść poprawy lub modyfikacji jego właściwości. Zmiany w zakresie składu chemicznego, morfologii czy też energii powierzchniowej biomateriału wpływają w sposób bezpośredni na odpowiedź żywej tkanki w obszarze kontaktowym. Możliwe z żywą tkanką interakcję mogą m.in. przyspieszać proliferację kolonii lub wpływać na jej śmiertelność warunkując zarówno reakcje pośrednie jej wzrostu, przyczepności czy też żywot-

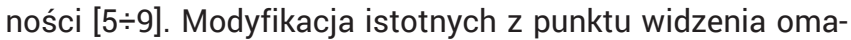
wianej grupy właściwości może z powyższych względów pozostawać w relacji sprzecznej.

W niniejszej pracy przedstawiono koncepcję innowacyjnego podejścia otrzymywania zmodyfikowanych pod kątem właściwości, mikrostruktury i składu fazowego warstw powierzchniowych, będących wynikiem zastosowania procesu stopowania plazmowego nanoprekursorów proszkowych. Zaproponowane podejście stopowania plazmowego [12] w innowacyjnej koncepcji jest wynikiem zmodyfikowania metody spawania plazmowego PAW (ang. Plasma Arc WeIding). Klasyfikując metody kształtowania struktury i właściwości powierzchni materiałów inżynierskich umiejscawiamy zastosowane w pracy podejście plazmowe, obok nowoczesnych cieplno-chemicznych metod stopowania laserowego i elektronowego powierzchni. Realizowany efekt w odniesieniu do technologii napawania czy dyspergowania polega na wzbogacaniu w dodatki stopowe warstw wierzchnich, zmianę właściwości materiału w wąskiej strefie przypowierzchniowej między innymi w wyniku przetapiania pierwiastków pochodzących z odpowiednio przygotowanego i naniesionego filmu mieszaniny. Istotą procesu jest przetopienie naniesionego filmu materiału stopującego oraz podłoża, gwałtowne nagrzanie niewielkiej objętości materiału, intensywne wymieszanie, a następnie krzepnięcie przy bardzo szybkim chłodzeniu. Powyższe warunki umożliwiają powstanie drobnokrystalicznej struktury, a także między innymi znaczne przesycanie roztworów stałych i możliwość powstawania faz metastabilnych.

Metoda spawania plazmowego znajduje bardzo szerokie zastosowanie przede wszystkim w technologiach przetwórczych. Doniesienia literaturowe wskazują również na wykorzystanie techniki PAW do naprawy ubytków jamy ustnej protez [10].

Wysoka gęstość energii na łatwo kontrolowalnym źródle sprawia, że zakres możliwych do realizacji procesów obróbki laserowej, staję się obecnie dostępny w niektórych obszarach dla metod plazmowych, co ważne przy niższych kosztach wstępnych i eksploatacyjnych [11]. Do istotnych zalet zaproponowanego podejścia należy zaliczyć: możliwość lokalnej obróbki, brak odkształceń przedmiotu obrabianego w wyniku stosowania chłodzenia podłoża oraz szerokie możliwości kształtowania struktury materiału, jego składu chemicznego i właściwości użytkowych.

\section{Materiały i metodologia}

Do stopowania mikroplazmowego powierzchni użyto nanoprekursory proszkowe wytworzone metodą mechanicznej syntezy. Proszki wejściowe tytanu oraz boru o wysokiej czystości poddano zmieszaniu w dwóch proporcjach wagowych zestawionych w tablicy I.

Mechaniczne mielenie tak przygotowanych mieszanin prowadzono przez 48h na młynku typu Spex8000, celem rozdrobnienia struktury oraz równomiernego rozłożenia składników kompozycji. Czynności naważenia, kontroli w trakcie procesu, jak i przechowywania prowadzono w atmosferze ochronnej argonu (99,999\%) w komorze rękawicowej LabMaster 130. Przygotowane kompozycje prekursorów proszkowych nanoszono w mieszaninie lepiszcza polimerowego na oczyszczone i odtłuszczone powierzchnie podłoża blachy tytanowej o grubości $3 \mathrm{~mm}$, której skład chemiczny zestawiono w tablicy II.

Tablica II. Skład chemiczny blachy podłożowej klasy Grade 2, przeznaczonej do stopowania plazmowego

Table II. The chemical composition of the Grade 2 substrate sheet, intended for plasma alloying

\begin{tabular}{|c|c|c|c|c|c|c|}
\hline \multirow{2}{*}{$\begin{array}{c}\text { Udział } \\
\text { wagowy } \\
{[\%]}\end{array}$} & \multicolumn{6}{|c|}{ Pierwiastek } \\
\cline { 2 - 7 } & $\mathbf{N}_{2}$ & $\mathbf{C}$ & $\mathbf{H}_{2}$ & $\mathbf{F e}$ & $\mathbf{O}_{2}$ & $\mathrm{Ti}$ \\
\hline $\begin{array}{c}\text { Pożądany } \\
\text { w klasie }\end{array}$ & $\begin{array}{c}0,03 \\
\max \end{array}$ & $\begin{array}{c}0,08 \\
\max \end{array}$ & $\begin{array}{c}0,015 \\
\max \end{array}$ & $\begin{array}{c}0,3 \\
\max \end{array}$ & $\begin{array}{c}0,25 \\
\max \end{array}$ & reszta \\
\hline $\begin{array}{c}\text { Wynik } \\
\text { analizy }\end{array}$ & 0,01 & 0,02 & 0,005 & 0,06 & 0,13 & reszta \\
\hline
\end{tabular}

Stopowanie plazmowe prowadzono celem uzyskania warstw powierzchniowych o odmiennych od podłoża właściwościach fizycznych z zachowaniem ciągłości metalurgicznej w strefie międzywarstwy. Powyższa metoda umożliwia stopowanie podłoża z naniesionym filmem proszkowym poprzez jego przetopienie wraz z wytworzeniem nowej warstwy powierzchniowej będącej wynikiem zachodzących procesów metalurgicznych zgodnie ze schematem ideowym (rys. 1). W wyniku reakcji w fazie ciekłej podłoża oraz stopowanego filmu prekursora dochodzi do wytworzenia warstwy powierzchniowej charakteryzującej się wysoką jednorodnością, drobnodyspersyjną mikrostrukturą oraz podwyższonymi właściwościami użytkowymi.

Tablica I. Parametry wejściowe proszków tytanu oraz boru wraz z zaproponowanymi układami mieszanin prekursorów Table I. Input parameters of titanium and boron powders with the proposed precursor mixture systems

\begin{tabular}{|c|c|c|c|c|c|c|}
\hline Pierwiastek & Czystość [\%] & Postać & $\begin{array}{c}\text { Rozmiar średni } \\
{[\mu \mathrm{m}]}\end{array}$ & Producent & $\begin{array}{c}\text { Mieszanina } 1 \\
\text { udział wagowy [\%] }\end{array}$ & $\begin{array}{c}\text { Mieszanina } 2 \\
\text { udział wagowy [\%] }\end{array}$ \\
\hline Tytan & 99,5 & proszek & 44 & Alfa Aesar & 98 & 90 \\
\hline Bor & 99,5 & proszek & 44 & Alfa Aesar & 2 & 10 \\
\hline \multicolumn{5}{|c|}{ Oznaczenie } & Ti-2B & Ti-10B \\
\hline
\end{tabular}



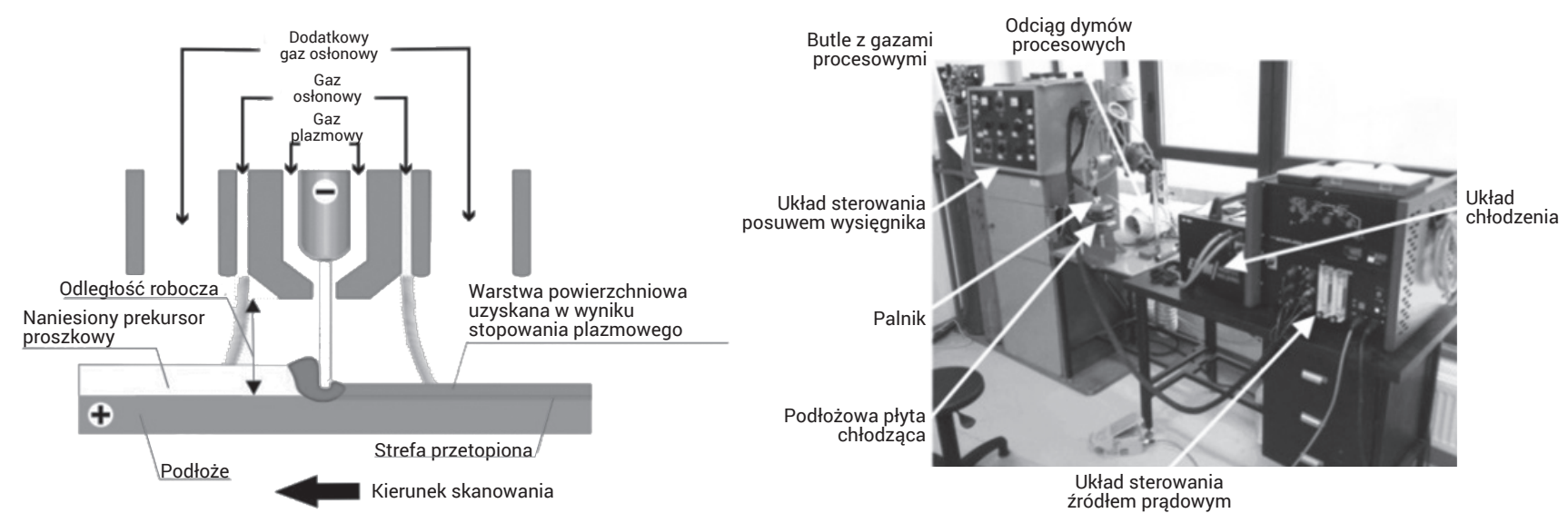

Rys. 1. Schemat ideowy procesu stopowania plazmowego wraz z widokiem stanowiska

Fig. 1. The schematic diagram of the plasma alloying process along with the view of the work station

Dla zaproponowanego rozwiązania użyto urządzenia mikroplazmowego EWM 50 dokonując modyfikacji celem stworzenia stanowiska roboczego jak ukazuje to rysunek 1 w zakresie:

- osadzenie palnika w uchwycie pozwalającym na sterowanie prędkością posuwu w osi x oraz położenia wysokości w osi z;

- zastosowanie stolika przesuwnego z możliwością zmiany położenia w osi y;

- zastosowanie podłożowej płyty chłodzącej w zespole przepływowym otwartym (20 l/min);

- zastosowanie dodatkowej tulei zapewniającej wleczony, laminarny przepływ dodatkowego gazu osłonowego celem przedmuchu podłoża i ograniczenia wpływu atmosfery zewnętrznej.

Procedurę stopowania prowadzono przy założeniu parametrów roboczych zestawionych w tablicy III.

Tablica III. Parametry procesu stopowania plazmowego powierzchni Table III. The parameters of the plasma alloying process

\begin{tabular}{|c|c|}
\hline Parametr & Wartość \\
\hline Natężenie prądu [A] & 28 \\
\hline Prędkość stopowania [mm/s] & 0,6 \\
\hline $\begin{array}{l}\text { Ilość materiału prekursora proszkowego } \\
\text { poddawana przetopieniu }\left[\mathrm{g} / \mathrm{m}^{2}\right]\end{array}$ & 850 \\
\hline Średnica dyszy [mm] & 1,6 \\
\hline Napięcie [V] & 10 \\
\hline Odległość robocza [mm] & 5 \\
\hline Średnica elektrody [mm] & 1,6 \\
\hline \multicolumn{2}{|l|}{ Przepływy gazów [l/min] } \\
\hline Gaz plazmowy & 0,1 \\
\hline Gaz osłonowy & 10 \\
\hline Dodatkowy gaz osłonowy & 10 \\
\hline \multicolumn{2}{|l|}{ Skład mieszanek gazowych } \\
\hline Gaz plazmowy & Argon \\
\hline Gaz osłonowy & Argon $-50 \% \mathrm{Hel}$ \\
\hline Dodatkowy gaz osłonowy & Argon \\
\hline Wymiary ścieżek roboczych [mm] & $20 \times 2 \times 0,1$ \\
\hline Rozmiar płytek podłożowych [mm] & $35 \times 20 \times 3$ \\
\hline
\end{tabular}

Materiał wejściowy mieszanin proszkowych jak również wytworzone warstwy powierzchniowe poddano analizie strukturalnej dyfraktometrem PanAnalytical Empyrean z lampą miedzianą. Wytworzone warstwy powierzchniowe badano pod kątem odporności korozyjnej w próbie potencjodynamicznej w roztworze $0,9 \% \mathrm{NaCl}$ stosując odniesienie do materiału podłoża niemodyfikowanego. Mikrostrukturę wytworzonych warstw analizowano w przekroju poprzecznym wraz z oceną zmian mikrotwardości metodą Vickersa przy obciążeniu $300 \mathrm{~g}$. Dla powierzchni zmodyfikowanych prowadzono badania cytokompatybilności z użyciem linii komórek ludzkich fibroblastów HGF-1 (ATCC $®$ CRL-2014 ${ }^{\mathrm{TM}}$ ) oraz osteoblastów U-2 OS (ATCC $\AA$ HTB-96 ${ }^{\text {TM }}$ ) po ich uprzedniej sterylizacji w autoklawie (120 ${ }^{\circ} \mathrm{C}$ przez $\left.15 \mathrm{~min}\right)$. Hodowle kolonii komórkowych prowadzono w inkubatorze przy stałych warunkach temperaturowych $37{ }^{\circ} \mathrm{C}$, wilgotności 95\% oraz atmosferze zawierającej $5 \%$ udział $\mathrm{CO}_{2}$. Dla powierzchni próbek o wymiarach około $1 \mathrm{~cm}^{2}$, aplikowano w 24 dołkowych płytkach hodowlanych medium robocze zawierające $3 \times 10^{4}$ komórek obu linii. Przeprowadzono analizę żywotności kolonii wraz z jej wizualizacją a po czasie $96 \mathrm{~h}$ dokonywano oceny przeżywalności medium, zliczając ilość komórek przy użyciu kamery hematologicznej komorą zliczeniową Fuchs-Rosenthal.

\section{Wyniki badań}

Przeprowadzona analiza strukturalna mieszanin prekursorów proszkowych z 2 oraz 10\% udziałem wagowym boru do tytanu (rys. 2) w trakcie syntezy potwierdza możliwość uzyskania rozdrobnienia materiału - widocznego na analizowanych widmach w postaci zmniejszenia intensywności refleksów oraz towarzyszącego im znacznego ich poszerzenia. Jednocześnie stwierdza się, przy podwyższonej koncentracji boru $\mathrm{w}$ mieszaninie, przyspieszenie procesu rozdrobnienia struktury z jednoczesnym homogenicznym rozkładem składników wejściowych w kompozycji. Załączone zdjęcia SEM obrazujące morfologię uzyskanych po czasie $48 \mathrm{~h}$ syntezy agregatów proszkowych potwierdzają również charakter zachodzących w trakcie procesu mechanicznej syntezy reakcji pomiędzy składnikami układu, dla których rozrzut wielkości mieści się w zakresie $5 \div 150 \mu \mathrm{m}$.

Uzyskane w wyniku stopowania mikroplazmowego warstwy powierzchniowe charakteryzują się drobnodyspersyjną i jednorodną budową (rys. 3 i 4) pozbawione są wad w postaci pęcherzy, niejednorodności czy braku przetopień, jak również charakteryzuje je trwałe połączenie metalurgiczne w układzie międzywarstwy. Załączona analiza strukturalna 


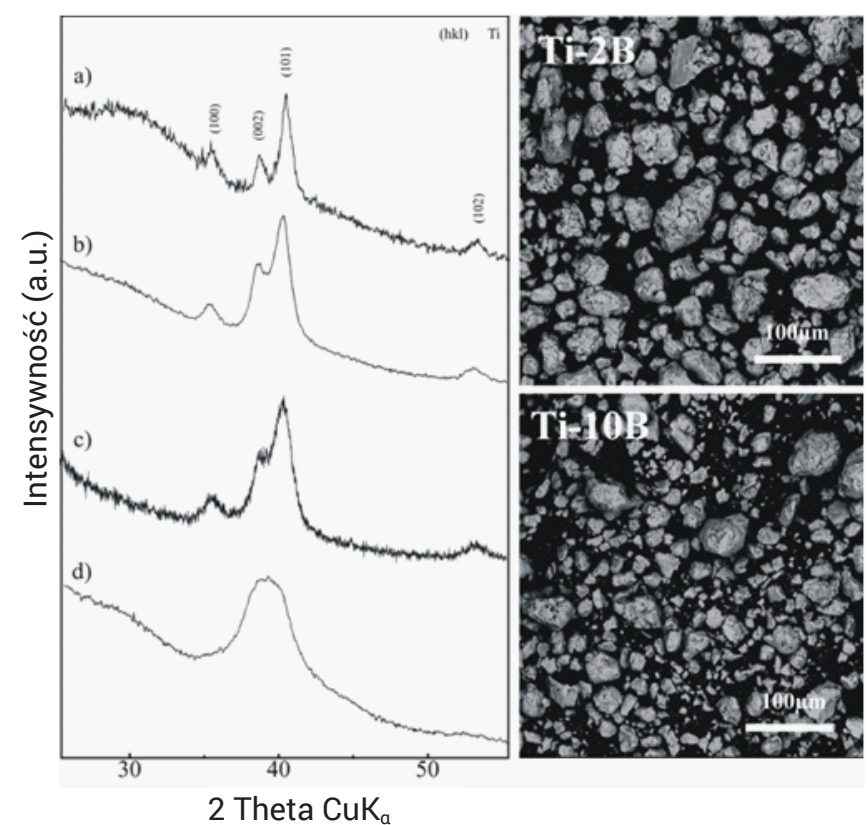

Rys. 2. Widma strukturalne prekursorów wejściowych poddane $24 \mathrm{~h}$ a), b) i 48 h c), d) syntezie dla $2 \%$ wag. B a), c) oraz $10 \%$ wag. B b), d) wraz z ich morfologią po 48h syntezy

Fig. 2. Structural spectra of input precursors subjected to $24 \mathrm{~h} a), b$ ) and $48 \mathrm{~h} \mathrm{c}$ ), d) synthesis for $2 \mathrm{wt. \%}$ B a), c) and $10 \mathrm{wt} \% \mathrm{~B} \mathrm{~b}$ ), d) with their morphology after $48 \mathrm{~h}$ synthesis z powierzchni potwierdza układ struktury dwufazowej kompozytowej składającej się z osnowy Ti oraz występujących wydzieleń fazy TiB, dla których wzrost udziału wagowego boru w mieszaninie prekursora wejściowego wpływa również na udział fazy wydzieleniowej.

Badania rozkładu twardości na przekroju analizowanych warstw powierzchniowych wskazują na znaczący jej wzrost w stosunku do materiału podłoża. Z poziomu bazowego twardości tytanu mikrokrystalicznego 180 HV0,3 do 850 HV0,3 a nawet 950 HV0,3 dla warstw powierzchniowych uzyskanych z materiału wejściowego nanoprekursora proszkowego z 2 lub 10\% wag. dodatkiem B.

Przeprowadzone pomiary potencjodynamiczne odporności korozyjnej wytworzonych warstw powierzchniowych w elektrolicie $0,9 \% \mathrm{NaCl}$, potwierdzają zbliżony zakres uzyskiwanych wartości prądu i potencjału korozyjnego do próbki bazowej tytanu mikrokrystalicznego (tabl. IV). Należy zaznaczyć w tym miejscu, iż wytworzone układy charakteryzują się dwufazową strukturą o znacznym stopniu dyspersji co w obu przypadkach powinno wpływać w sposób negatywny na analizowane cechy.

Celem oceny przydatności aplikacyjnej wytworzonych metodą stopowania plazmowego warstw powierzchniowych o odmiennych od podłoża właściwościach w aspekcie biologicznym, wytworzone układy analizowano w kontakcie z medium hodowlanym dwóch typów kolonii komórkowych fibroblastów i osteoblastów. Znając koncentracje wejściową
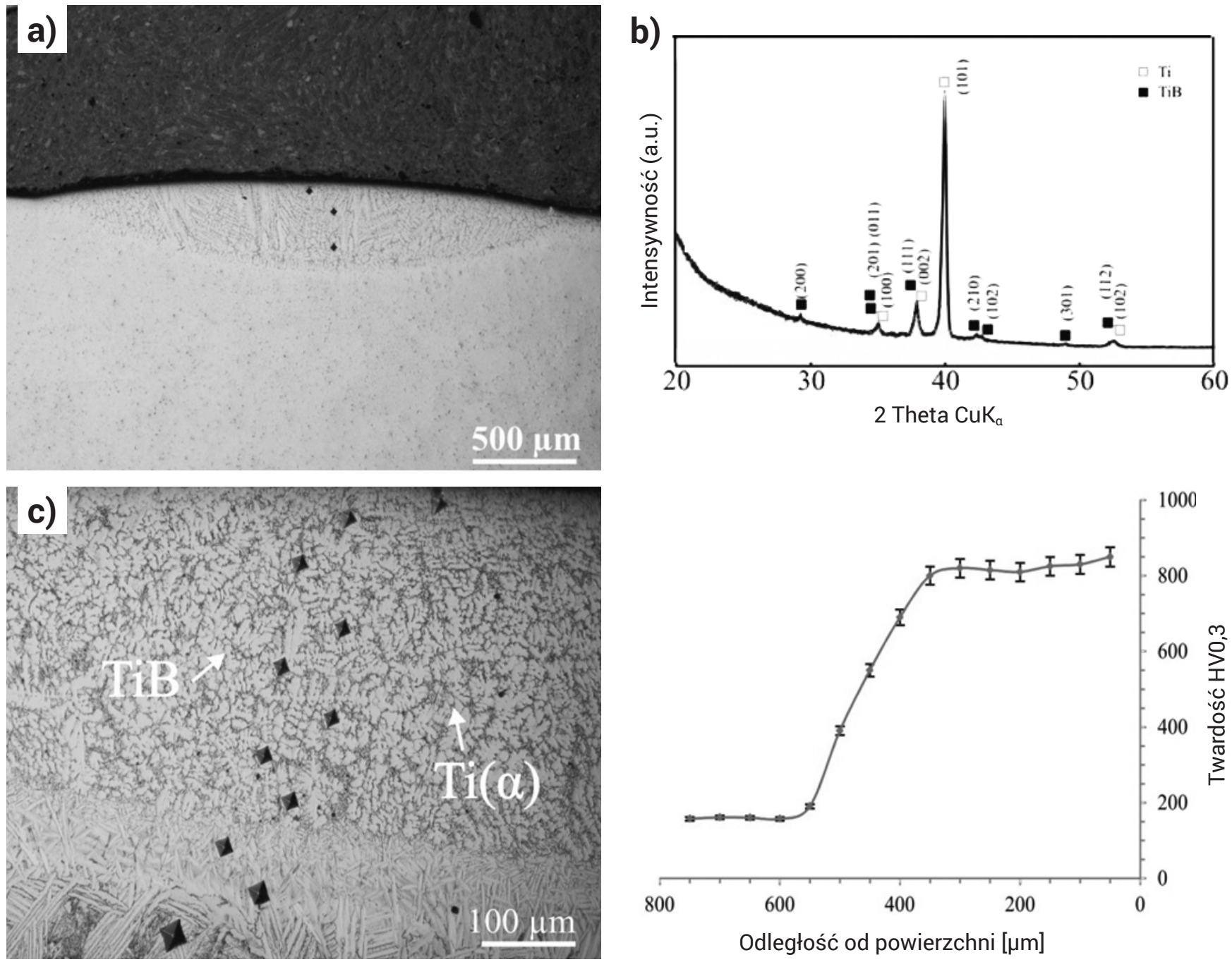

Rys. 3. Przekrój poprzeczny warstwy powierzchniowej: a) wraz z analizą strukturalną, b) widokiem między warstwy, c) oraz rozkładem mikrotwardości układów uzyskanych z materiału wejściowego nanoprekursora proszkowego z $2 \%$ wag. B

Fig. 3. Cross-section of the surface layer. a) along with structural analysis, b) interlayer view, c) and microhardness distribution profile of the system obtained from the nanoprecursor powder input material with $2 \mathrm{wt}$ \% B 


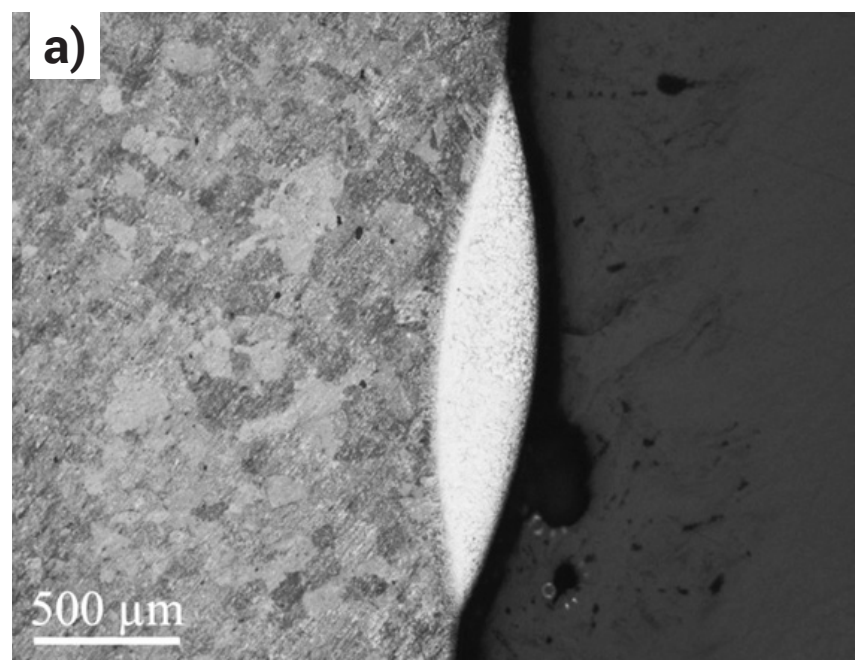

b)
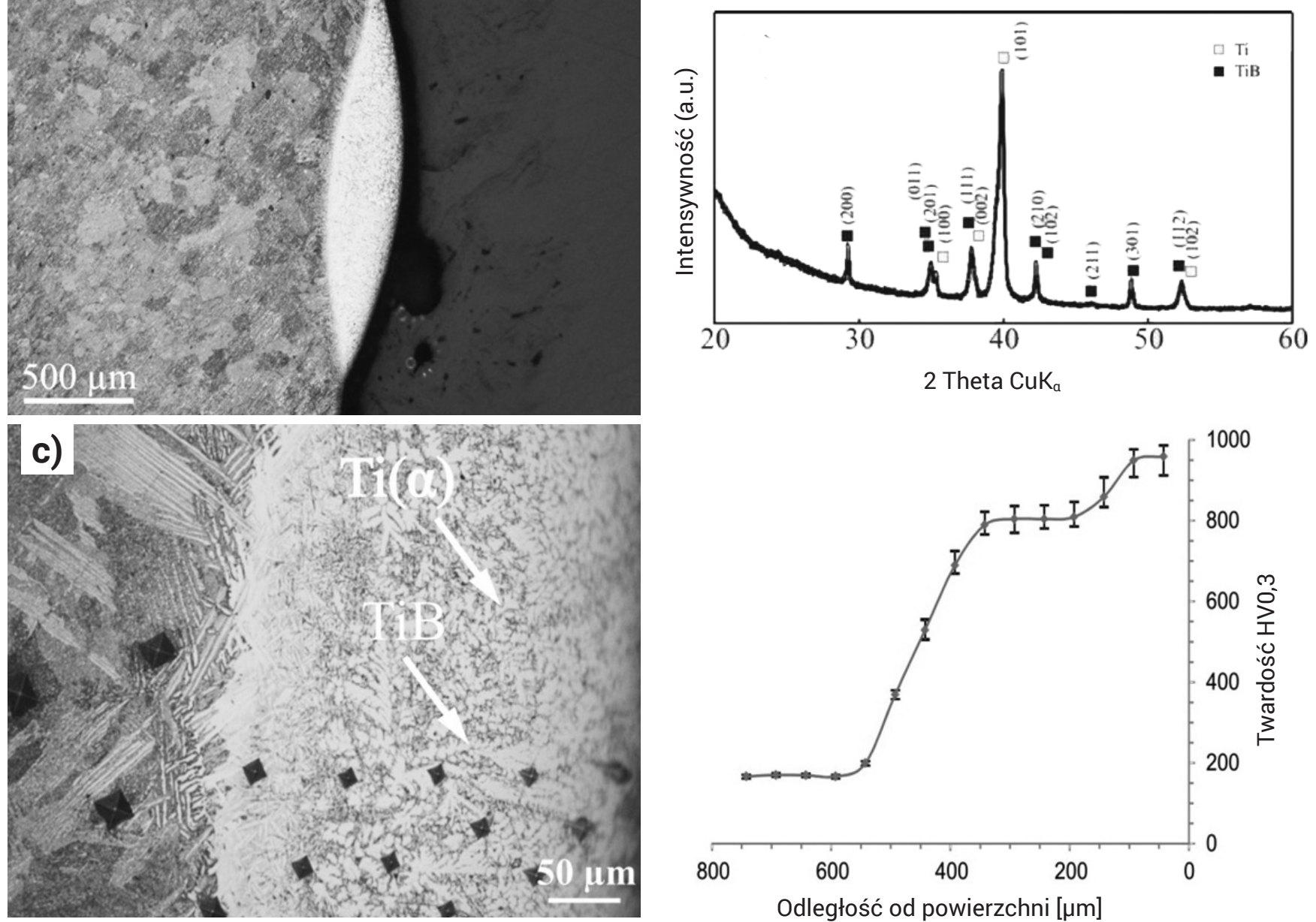

Rys. 4. Przekrój poprzeczny warstwy powierzchniowej: a) wraz z analizą strukturalną, b) widokiem między warstwy, c) oraz rozkładem mikrotwardości układów uzyskanych z materiału wejściowego nanoprekursora proszkowego z $10 \%$ wag. B

Fig. 4. Cross-section of the surface layer. a) along with structural analysis, b) interlayer view, c) and microhardness distribution profile of the system from the nanoprecursor powder input material with $10 \mathrm{wt} . \% \mathrm{~B}$

Tablica IV. Zestawienie tabelaryczne wyników pomiaru potencjodynamicznego wartości prądu i potencjału korozyjnego badanych próbek

Table IV. Tabular summary of the results of potentiodynamic current and corrosion potential measurements of the tested samples

\begin{tabular}{|c|c|c|}
\hline $\begin{array}{c}\text { Próbka badana } \\
\text { w elektrolicie } \mathbf{0 , 9 \%} \text { wag. NaCl } \\
\text { w zakresie potecjału -2 do 2V } \\
\text { przy kroku pomiarowym } \mathbf{0 , 5} \mathbf{~ m V / s}\end{array}$ & $\begin{array}{c}\mathbf{i}_{\text {corr }} \\
{\left[\mathbf{\mu A} / \mathbf{c m}^{2}\right]}\end{array}$ & $\begin{array}{c}\mathbf{V}_{\text {corr }} \\
\text { [V] }\end{array}$ \\
\hline Podłoże tytan mikrokrystaliczny TiG2 & 0,515 & $-0,319$ \\
\hline $\begin{array}{c}\text { Warstwa stopowana plazmowo nano } \\
\text { 2\% wag. B }\end{array}$ & 0,214 & $-0,354$ \\
\hline $\begin{array}{c}\text { Warstwa stopowana plazmowo nano } \\
\text { 10\% wag. B }\end{array}$ & 0,739 & $-0,214$ \\
\hline
\end{tabular}

komórek w medium hodowlanym ocenie poddano żywotności kolonii wraz z jej śmiertelnością w dwóch interwałach czasowych. Przy użyciu mikroskopii optycznej i fluorescencyjnej analizowano żywotność kolonii odnosząc ją do próbki kontrolnej (roztwór czysty medium hodowlanego) oraz próbki bazowej (tytan mikrokrystaliczny). Z załączonych na rysunku 5 danych wynika, iż wszystkie analizowane powierzchnie wpływały w sposób zbliżonym na żywotności koIonii. Dla kolonii fibroblastów najlepsze wyniki w odniesieniu do próbki kontrolnej uzyskały z wynikiem 29\% próbka bazowa oraz próbka po stopowaniu plazmowym nanoprekursorem proszkowym z $2 \%$ wag. B. Dla kolonii osteoblastów najlepsze wyniki w odniesieniu do próbki kontrolnej wykazała próbka bazowa z wynikiem $21 \%$, a następnie próbka po stopowaniu plazmowym nanoprekursorem proszkowym z 10\% wag. B z wynikiem na poziomie $20 \%$.

Badana relacja w odniesieniu do próbki bazowej (słupek czarny - rys. 5), wskazuje na zbliżony poziom żywotności kolonii w wytworzonych układach warstw powierzchniowych w odniesieniu do materiału stosowanego powszechnie między innymi w aplikacjach implantów stomatologicznych.

Zestawienie końcowe śmiertelności kolonii analizowane w czasie 72 oraz 96 h pozwala na ocenę wpływu jej kontaktu z powierzchnią i tym samym ilościowe odzwierciedlenie występujących relacji. Przedstawione dane wskazują w przypadku kolonii fibroblastów na przyrost martwych komórek w odniesieniu do próbki po stopowaniu plazmowym nanoprekursorem proszkowym z 10\% wag. B już po 72 h na poziomie $10 \%$, by osiągnąć wartość końcową po czasie $96 \mathrm{~h}$ na poziomie $27 \%$, gdzie dla próbki bazowej czas $96 \mathrm{~h}$ powoduje śmiertelność kolonii na poziomie $20 \%$. Próbka po stopowaniu plazmowym nanoprekursorem proszkowym z $2 \%$ wag. B wykazuje poziom śmiertelności kolonii zbliżony do próbki kontrolnej.

W przypadku analizy śmiertelności kolonii osteoblastów na powierzchniach badanych uzyskiwane wyniki nie przekraczają poziomu 5\%. 

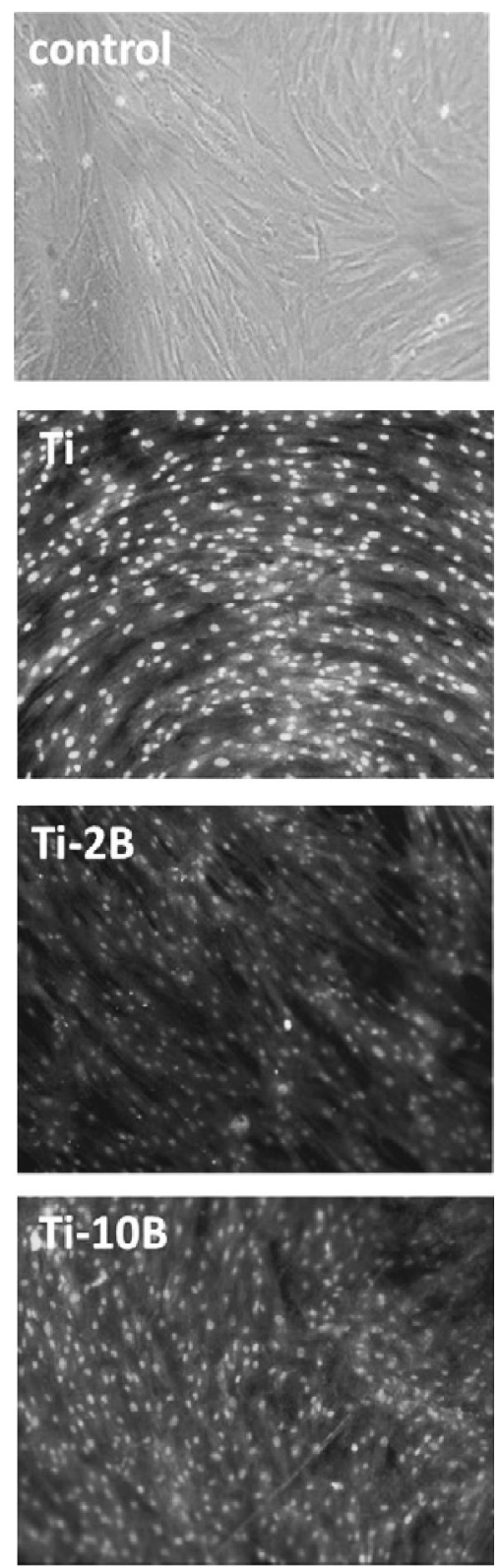

KOLONIA FIBROBLASTÓW

HGF-1
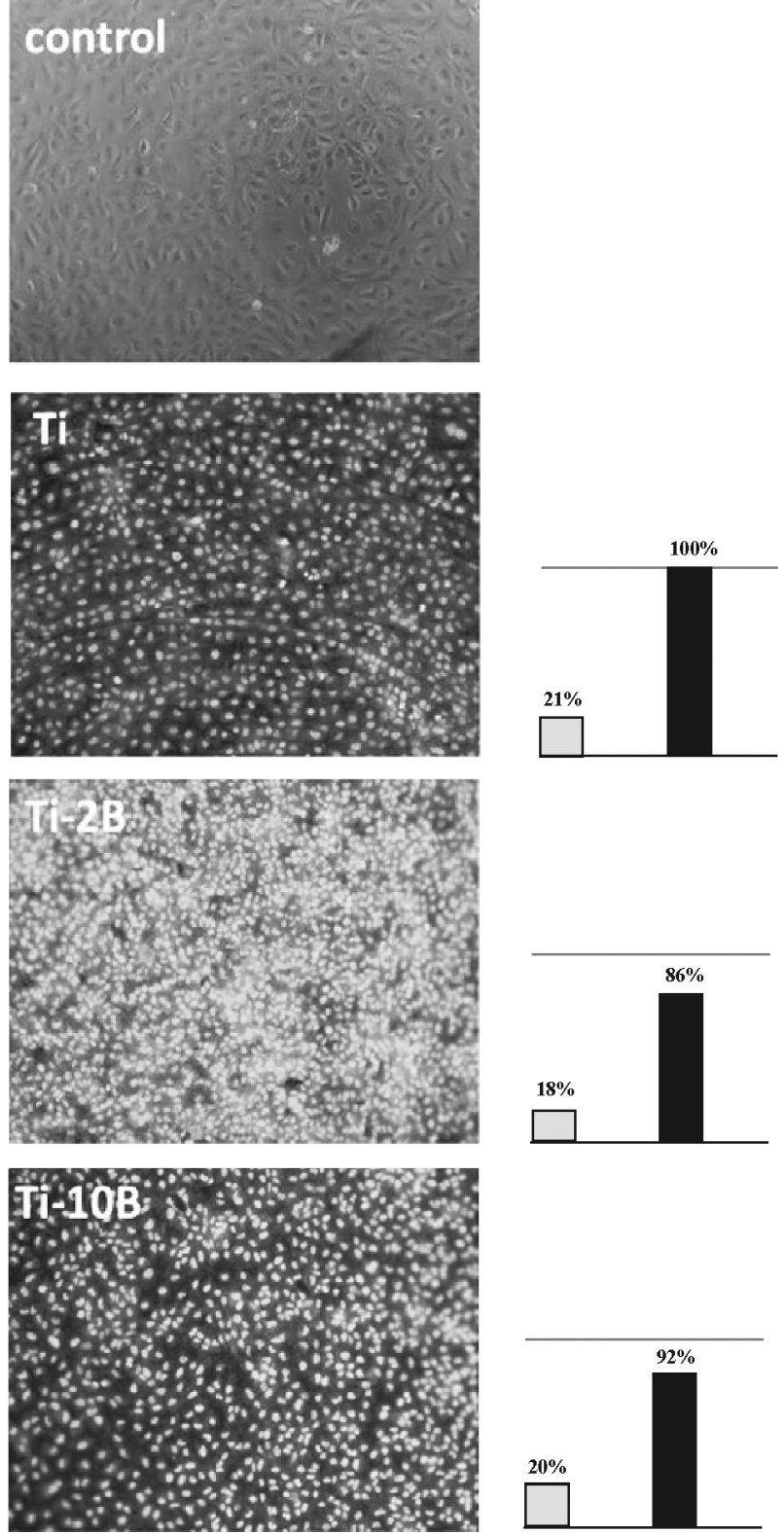

KOLONIA OSTEOBLASTÓW

$\mathrm{U}-2$ OS

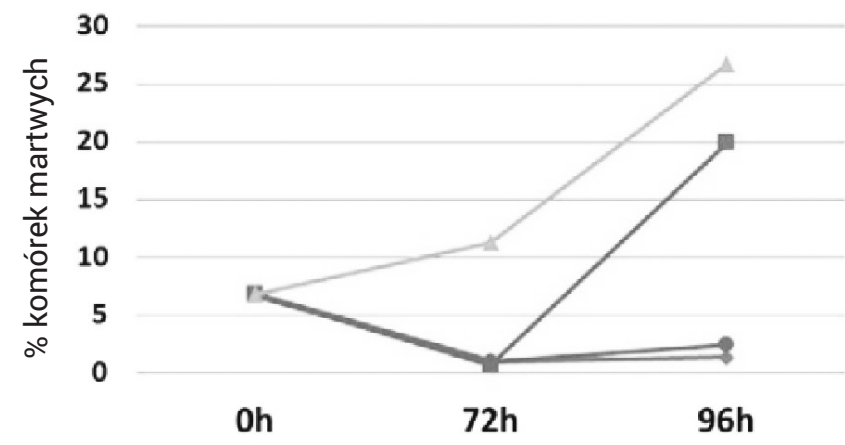

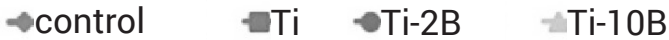

Rys. 5. Widok kolonii komórkowych na powierzchniach analizowanych w testach żywotności (mikroskopia optyczna i fluorescencyjna) wraz z układem odniesienia do próbki kontrolnej (słupek szary) i próbki bazowej - tytanu mikrokrystalicznego (słupek czarny) a także testy śmiertelności kolonii w dwóch interwałach czasowych

Fig. 5. View of cell colonies on surfaces analyzed in viability tests (optical and fluorescence microscopy) with a reference system for the control sample (gray bar) and the basal sample - microcrystalline titanium (black bar) as well as colony mortality level tests in two time intervals 


\section{Wnioski}

Przeprowadzone badania potwierdzają możliwość wytworzenia warstw powierzchniowych o odmiennych od podłoża właściwościach z prekursorów nanokrystalicznych przy użyciu metody stopowania plazmowego. Przeprowadzone badania in vitro cytokompatybilności z użyciem linii ludzkich komórek fibroblastów oraz osteoblastów na powierzchniach modyfikowanych w odniesieniu do próbki bazowej tytanu mikrokrystalicznego potwierdza, iż wytworzone układy mogą znaleźć potencjalne zastosowanie w zakresie modyfikacji implantów stomatologicznych czy też innych aplikacjach medycznych. Z przeprowadzonych analiz wynika, iż stopowanie mikroplazmowe jest efektywną metodą wytwarzania warstw kompozytowych typu Ti+TiB o możliwym szerszym aspekcie aplikacyjnym.

\section{Literatura}

[1] Miklaszewski A., Jurczyk M.U., Jurczyk K., Jurczyk M.: Plasma surface modification of titanium by TiB precipitation for biomedical applications, Surface \& Coatings Technology, 2011, 206, pp. 330-337.

[2] Miklaszewski A., Jurczyk M.U., Jurczyk M.: Microstructural Development of Ti-B Alloyed Layer for Hard Tissue Applications, J. Mater. Sci. Technol., 2013, 29, 6, pp. 565-572.

[3] Kaczmarek M., Jurczyk M. U., Miklaszewski A., Paszel-Jaworska A., Romaniuk A., Lipińska N., Żurawski J., Urbaniak P., Jurczyk K.: In vitro biocompatibility of titanium after plasma surface alloying with boron, Materials Science and Engineering: C ,2016, Vol. 69, pp. 1240-1247.

[4] Wang K.: The use and properties of titanium and titanium alloys for medical applications in the USA, Material Science and Engineering A 213, 1996, pp. 134-137.

[5] Guehennec L., Souedan A., Layrolle P., Amouriq Y.: Surface treatments of titanium dental implants for rapid osseointegration, Dental Materials 23, 2006, pp. 844-854.

[6] Ryan G., Pandit A., Apatsidis D. P.: Fabrication methods of porous metals for use in orthopaedic applications, Biomaterials 27, 2006, pp. 2651-2670.
[7] Boyan B. D., Hummert T. W., Dean D. D., Schwartz Z.: Role of material surfaces in regulating bone and cartilage cell response, Biomaterials 17, 1996, pp. 137-146.

[8] Rønold H. J., Ellingsen J. E.: Effect of micro-roughness produced by $\mathrm{TiO}_{2}$ blasting-tensile testing of bone attachment by using coin-shaped implants, Biomaterials 23, 2002, pp. 4211-4219.

[9] Mendonça G., Mendonça D. B. S., Aragão F. J. L., Cooper L. F.: Advancing dental implant surface technology - from micron- to nanotopography, Biomaterials 29, 2008, pp. 3822-3835.

[10] Xu Y.L., Wang K.H., Liu Y.: Reaserch on micro plasma arc welding of Co-Cr alloy metal in oral cavity repair, Electric Welding Machine, 2003, 133, 6, pp. 36-38.

[11] Jiang Y., Xu B., Lu Y., Xiang Y., Liu C., Xia D.: Application prospects of plasma welding within remanufacturing engineering, Beijing: National Plant Engineering R\&D Center, 2008.

[12] Miklaszewski A., Jurczyk M.U., Jurczyk M.: Modyfikacja warstwy wierzchniej biomateriałów na przykładzie tytanu metodą stopowania plazmowego, Przegląd Spawalnictwa, 2011, 12, s. 65-69. 